\title{
Extracellular Vesicles: A New Frontier in Biomarker Discovery for Non-Alcoholic Fatty Liver Disease
}

\author{
Linda A. Ban ${ }^{1}$, Nicholas A. Shackel ${ }^{2}$ and Susan V. McLennan ${ }^{1, *}$ \\ 1 Greg Brown Diabetes and Endocrine Laboratory, Charles Perkins Centre, University of Sydney, NSW 2006, \\ Australia; linda.ban@sydney.edu.au \\ 2 Liver Cell Biology Laboratory, Centenary Institute of Cancer Medicine and Cell Biology, Camperdown, \\ NSW 2006, Australia; n.shackel@centenary.usyd.edu.au \\ * Correspondence: sue.mclennan@sydney.edu.au; Tel.: +61-2-8627-1892
}

Academic Editors: Amedeo Lonardo and Giovanni Targher

Received: 24 February 2016; Accepted: 2 March 2016; Published: 14 March 2016

\begin{abstract}
In recent years, the global burden of obesity and diabetes has seen a parallel rise in other metabolic complications, such as non-alcoholic fatty liver disease (NAFLD). This condition, once thought to be a benign accumulation of hepatic fat, is now recognized as a serious and prevalent disorder that is conducive to inflammation and fibrosis. Despite the rising incidence of NAFLD, there is currently no reliable method for its diagnosis or staging besides the highly invasive tissue biopsy. This limitation has resulted in the study of novel circulating markers as potential candidates, one of the most popular being extracellular vesicles (EVs). These submicron membrane-bound structures are secreted from stressed and activated cells, or are formed during apoptosis, and are known to be involved in intercellular communication. The cargo of EVs depends upon the parent cell and has been shown to be changed in disease, as is their abundance in the circulation. The role of EVs in immunity and epigenetic regulation is widely attested, and studies showing a correlation with disease severity have made these structures a favorable target for diagnostic as well as therapeutic purposes. This review will highlight the research that is available on EVs in the context of NAFLD, the current limitations, and projections for their future utility in a clinical setting.
\end{abstract}

Keywords: biomarkers; diagnosis; exosomes; extracellular vesicles; microvesicles; NAFLD; non-alcoholic steatohepatitis (NASH); steatosis; steatohepatitis

\section{Introduction}

Obesity is rapidly evolving into a global pandemic, and poses a significant healthcare and socioeconomic burden. Its increased prevalence in both developed and developing nations has seen a rise in other serious metabolic complications, such as cardiovascular disease, type 2 diabetes mellitus and non-alcoholic fatty liver disease (NAFLD). Although diabetes is a common risk factor for NAFLD progression and vice versa [1-4], lean or non-diabetic patients also develop NAFLD [5-7], and so biochemical rather than anthropometric parameters would likely be of greater utility in diagnosis or prognosis of the disease.

To address this issue, the World Gastroenterology Organisation (WGO) recently published a set of comprehensive guidelines on the assessment and management of NAFLD [8], with emphasis on the distinction between simple steatosis and non-alcoholic steatohepatitis (NASH). The latter represents the advanced manifestation of the NAFLD spectrum whereby inflammation and fibrosis are also present, and is a condition which is much easier to identify than simple steatosis. However, limitations with current diagnostic methods, such as unreliable imaging techniques and serum markers, have meant that tissue biopsy remains the gold standard for NASH diagnosis [9-14]. Irrespective of this, biopsy is a highly invasive procedure and subject to variability through sampling error [15-17]. 
Moreover, it cannot predict disease progression, and, for this reason, there is increasing emphasis on the identification of stable non-invasive markers specific for liver disease progression.

At this stage, effective early detection is poor as patients usually do not report symptoms until they have progressed to NASH or cirrhosis. Serum biochemistry that reveals elevated liver transaminases in the absence of excessive alcohol consumption or other liver disease is the most typical indicator of NAFLD, while anthropometric data such as a high body mass index (considered obese if above $35 \mathrm{~kg} / \mathrm{m}^{2}$ ) may warrant further screening for visceral fat accumulation in the liver [8]. It must nonetheless be stressed that despite the increased likelihood, not all obese individuals will develop NAFLD/NASH, and so probing for markers of steatosis in global metabolic disorders should therefore address what is known about the mechanisms of disease within the target organ. Ideal marker candidates should reflect not only the presence of NAFLD, but also the severity of disease, which is vital for early diagnosis as well grading progression [13].

This review aims to introduce the concept of using circulating cell-derived vesicles as novel markers of NAFLD, with an emphasis on their role in diagnosis and the assessment of disease pathology. Drawing on recent evidence from the literature, the paradigm of "marker versus mediator" will be discussed, as well as insight into their potential as therapeutic targets.

\section{Novel Biomarkers in Liver Disease}

In the latter half of the last century, shedding of vesicles from the cell membrane was identified as an inconsequential by-product of cell degradation [18,19]. However, clinical studies supported by research findings have recently pointed to the regulated secretion of these extracellular vesicles and their role in intercellular communication. Moreover, the abundance as well as the phenotype of circulating vesicles is reported to change in many disease states, including liver diseases [20-23] and metabolic disorders such as diabetes and obesity [24-27]. As such, much interest has been invested in characterising these structures for their potential utility in diagnostics, especially for conditions where this is otherwise notoriously difficult, such as NAFLD.

\subsection{Extracellular Vesicles: What Are They?}

Extracellular vesicles (EVs) are collectively represented by three subclasses of membrane-bound structures that are distinguished based on their size, typical markers, and biogenesis [28-30] (see Figure 1). Exosomes are the smallest vesicles, usually below $100 \mathrm{~nm}$ in diameter, and are formed within multivesicular bodies (MVB) that release their contents into the interstitium upon fusion with the cell membrane. These exocytosed EVs are characterised by their expression of membrane tetraspanins, most notably CD63, as well as the endosomal sorting complex required for transport (ESCRT)-associated protein Alix, both of which reflect the MVB origin of exosomes [29,31,32].

In contrast, microvesicles (MVs) are shed directly from the cell membrane by a "budding" process and typically range in size from around 100 to $1000 \mathrm{~nm}$, although these values are somewhat arbitrary and subclass overlap may exist [29]. MVs are identified by the expression of phosphatidylserine (PS) on their surface, which is indicative of their release from activated or apoptotic cells. In these cells PS is externalized, whereas in quiescent cells the membrane PS has a cytosolic orientation $[33,34]$. Most studies utilise the fact that Annexin V-a soluble protein used in the detection of apoptotic cells_-binds with high affinity to PS and is therefore a useful marker of the MV subclass. Meanwhile, some groups have argued that a majority of circulating MVs are in fact PS-negative, whilst others have proposed that measurement of lactadherin may be a more sensitive alternative to Annexin V [35-37]. Despite ongoing controversies in their characterisation, both EV populations have ultimately been shown to impart functional properties of their parent cells through the transfer of proteins, mRNAs, and particularly microRNAs (or miRNAs) that are subsequently involved in epigenetic regulation [38,39]. 


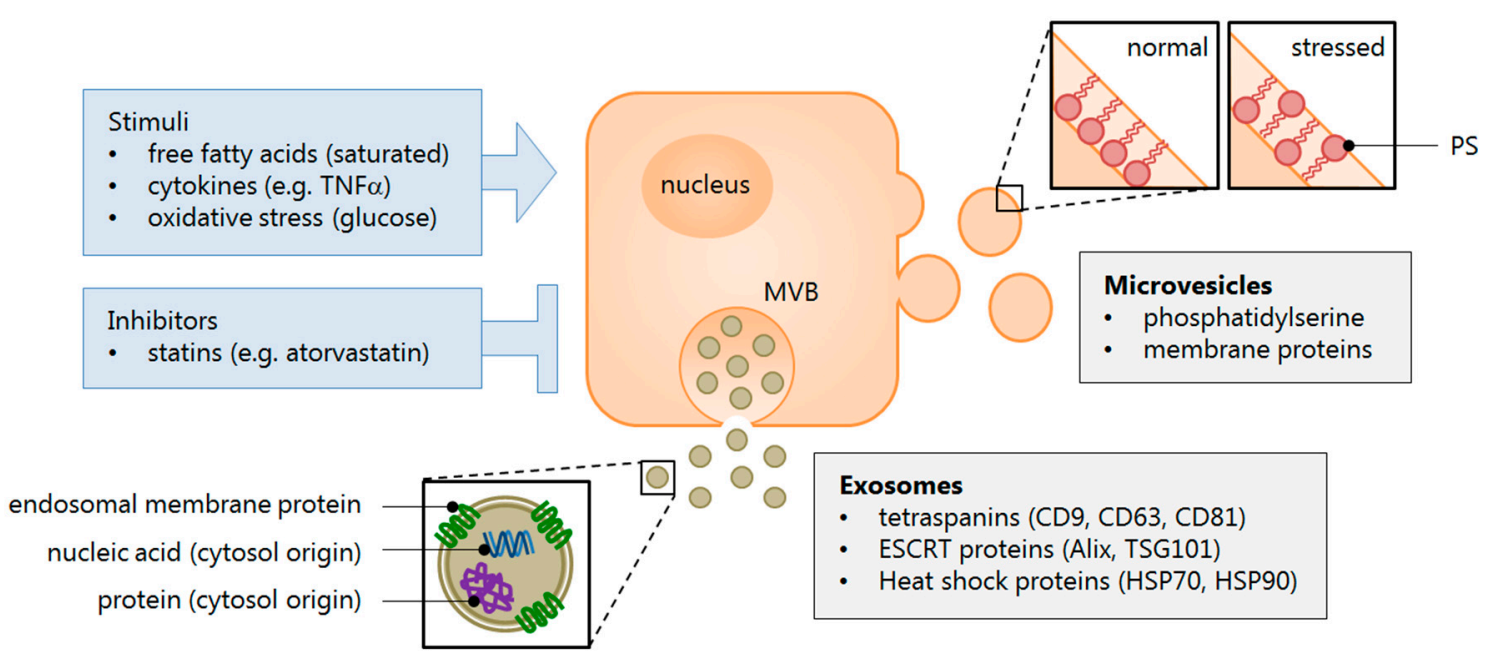

Figure 1. Extracellular vesicle characterisation. Cells respond to a variety of stimuli that cause inflammation and metabolic stress, which result in their activation, impaired functioning, or apoptosis. This mechanism drives the release of extracellular vesicles (EVs), which signal to paracrine or distal effectors the condition of the cell microenvironment. Effector cells may, in turn, respond by selectively imparting regulatory molecules—small nucleic acids (mRNA and miRNA), lipids, and proteins-contained within EVs, that are taken up by the recipient cell. The EV subclasses are identified by membrane markers that denote the site of their biogenesis. Exosomes typically express endosomal membrane proteins, such as tetraspanins, while microvesicles are understood to contain phosphatidylserine. These lipoproteins are normally oriented towards the cytosol to maintain the cell membrane asymmetry, but during conditions that stimulate EV release, the molecules become everted. Abbreviations: ESCRT = endosomal sorting complex required for transport; $\mathrm{MVB}=$ multivesicular body; PS = phosphatidylserine.

Finally, apoptotic bodies represent the largest EV subclass in terms of their size, ranging from one to four microns. Since this is comparable with platelets, studies that use size exclusion techniques to isolate circulating EVs, such as ultracentrifugation or filtration, will usually lose this population of vesicles with larger contaminants [40]. Furthermore, as apoptotic bodies are formed during the compartmentalization of apoptotic cells, they are generally assumed to be inert particles destined for phagocytosis, although their horizontal gene-transfer capacity has been documented [41,42].

\subsection{Role of Extracellular Vesicles in Liver Disease}

Almost all cell types ubiquitously release low levels of extracellular vesicles. In normal physiology, most circulating EVs are derived from platelets and endothelial cells, and have been shown to be important in common haemostatic events such as coagulation [43]. While vesicles of the same origin have been implicated in disease complications of a pro-coagulative nature $[44,45]$, there is still a paucity of knowledge regarding the dynamics of EV secretion by different cell types and in particular how the secreted EVs interact to advance the pathogenesis of a given disease. Controlled in vitro experiments have provided the most direct lines of evidence for EV regulation, including how the stimulus for release may affect their phenotype [46]. There is a wealth of research using liver injury models to explore EV-mediated fibrosis [47-49], transcriptomic signalling [50-54], and targeted immunotherapy [55-57] in artificial cell culture systems. However, in vivo studies present an added degree of complexity due to the difficulty of identifying liver specific EVs within the circulating pool. For this reason, most studies have opted to focus on circulating vesicle characterisation and their temporal changes in relation to liver disease development [58-63], while others have pointed to roles in extrahepatic cancer metastasis to the liver [64-66], although functional relationships have yet to be explored. 
Some groups have approached the study of EVs from a more organ-targeted perspective, assessing their role as paracrine mediators. Most of these studies evaluate the effect of EVs in fibrogenesis, for example, the shuttling of pro-fibrogenic connective tissue growth factor (CTGF) between hepatic stellate cells on the one hand [47], or the CTGF inhibiting miRNA-214 between stellate cells and hepatocytes or adjacent stellate cells on the other hand [48]. Immune-mediated modulation has also been suggested; one study had demonstrated a role for T cell-derived EVs in the induction of stellate cell fibrolytic activity, as defined by an increase in the gene expression of matrix metalloproteinases (MMPs) [49]. The findings concluded that this response from the stellate cells was likely mediated by the homodimeric interaction of CD147 at the EV-cell interface. A pro-inflammatory glycoprotein, CD147 had previously been implicated in liver disease pathogenesis by our group $[67,68]$ as well as having a well document role in tumour metastasis, which more recently had been attributed to EV-mediated translocation [69-71]. Secreted vesicles have also been linked to paracrine signalling in the tumour microenvironment, whereby miRNAs shuttled from hepatoma cells were able to modulate protein expression in adjacent hepatocytes and to increase their proliferative potential $[50,51]$. Silencing of these miRNAs, in turn, had abrogated the pro-tumorigenic effects, while another study had suggested a role for liver stem cell-derived EVs in miRNA-mediated tumour suppression [52].

\subsection{Markers or Mediators of Liver Disease?}

Taken together, this body of evidence highlights the growing expanse of EV research pertaining to liver disease, and on the contrary, a relative paucity of data regarding the involvement of EVs in NAFLD progression to NASH. Additionally, it introduces the "marker versus mediator" paradigm when addressing the functionality of EVs. This plays an important role in EV analysis; for instance, in the context of NAFLD, global changes in the circulating pool (marker) may not reflect the local interactions within specific tissues, such as the liver, that drive pathogenesis at these sites (mediator). However, a circulating profile that is unique to a given disease etiology would still substantiate the use of EVs as non-invasive diagnostic markers, a concept that is discussed further in the section below.

\section{Studies in Non-Alcoholic Fatty Liver Disease}

Liver research involving EVs as disease mediators faces a number of inherent challenges. The most important of these is finding a link between the circulating EV populations and a specific contribution from the liver. From a biomarker perspective, it could be argued that a quantitative or phenotypic change in circulating EVs with disease may validate their diagnostic utility, especially if these changes are intensified with NAFLD progression (see Table 1). Unfortunately, given the complex biological determinants of EV secretion, rather than a linear relationship we are more likely to see dynamic responses from different tissues during the course of pathogenesis (see Figure 2). For a start, NAFLD is not an isolated condition and, generally speaking, occurs as a complication of other metabolic disorders where global insulin resistance is also present. Therefore, multiple tissues may be affected by the resulting oxidative stress and fatty acid flux, which in turn promotes the activation of immune cells and their migration to these sites. Consequently, the extrahepatic release of EVs may in fact mask the pathogenesis of NAFLD. For this reason, and the lack of a specifically hepatic molecular marker, ideal studies should examine the circulating EVs against their liver-derived counterparts, where possible. 
Table 1. Extracellular vesicle markers in non-alcoholic fatty liver disease (NAFLD) studies.

\begin{tabular}{|c|c|c|c|c|}
\hline Vesic & e Source & Marker(s) & Key Study Findings & Citation \\
\hline \multirow{6}{*}{ Circulating } & Lymphoid cells & $\begin{array}{c}\mathrm{CD} 4 \\
\mathrm{CD} 8 \\
\mathrm{Va} 24 / \mathrm{Vb} 11\end{array}$ & $\begin{array}{l}\text { Enriched in NAFLD, positively correlated with } \\
\text { serum ALT and liver biopsy }\end{array}$ & [72] \\
\hline & Myeloid cells & $\begin{array}{l}\text { CD14 } \\
\text { CD15 }\end{array}$ & 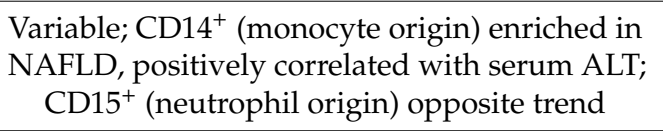 & [72] \\
\hline & Erythrocytes & TER119 & $\begin{array}{l}\text { Comprise the majority of circulating EVs } \\
\text { during Western diet }\end{array}$ & [73] \\
\hline & Platelets & $\begin{array}{l}\text { CD41 } \\
\text { CD62P }\end{array}$ & $\begin{array}{l}\text { Conflicting data for abundance in NAFLD; } \\
\text { reduced with statin intervention }\end{array}$ & {$[72,74]$} \\
\hline & Liver & $\begin{array}{l}\text { ASGPR1 } \\
\text { CES1 } \\
\text { miR-122 } \\
\text { miR-192 }\end{array}$ & $\begin{array}{l}\text { Enriched in NAFLD; miR-122 and miR-192 } \\
\text { correlated with decreased liver expression }\end{array}$ & [75-77] \\
\hline & Endothelial & CD144 & $\begin{array}{l}\text { Enriched in NAFLD; reduced with } \\
\text { statin intervention }\end{array}$ & [74] \\
\hline \multirow[t]{2}{*}{$\begin{array}{l}\text { Tissue } \\
\text { derived }\end{array}$} & Adipose & $\begin{array}{l}\text { adiponectin } \\
\text { IL-6 } \\
\text { MCP-1 } \\
\text { MIF }\end{array}$ & $\begin{array}{c}\text { Enriched in adipose origin; with the exception } \\
\text { of adiponectin, enriched in visceral versus } \\
\text { subcutaneous adipose }\end{array}$ & [78] \\
\hline & Hepatocytes & Vanin-1 & $\begin{array}{c}\text { Enriched in steatotic hepatocytes (HepG2 cells } \\
\text { treated with palmitate) }\end{array}$ & [76] \\
\hline
\end{tabular}

Abbreviations: ALT $=$ alanine transaminase; ASGPR1 = asialoglycoprotein receptor 1 ; CES1 = (liver) carboxylesterase 1; IL-6 = interleukin 6; iNKT = invariant natural killer T [cell]; MCP-1 = monocyte chemotactic protein $1 ; \mathrm{MIF}=($ macrophage $)$ migration inhibitory factor; NAFLD = non-alcoholic fatty liver disease; $\mathrm{Va} 24 / \mathrm{Vb} 11=\mathrm{T}$ cell receptor covariants a24/b11.

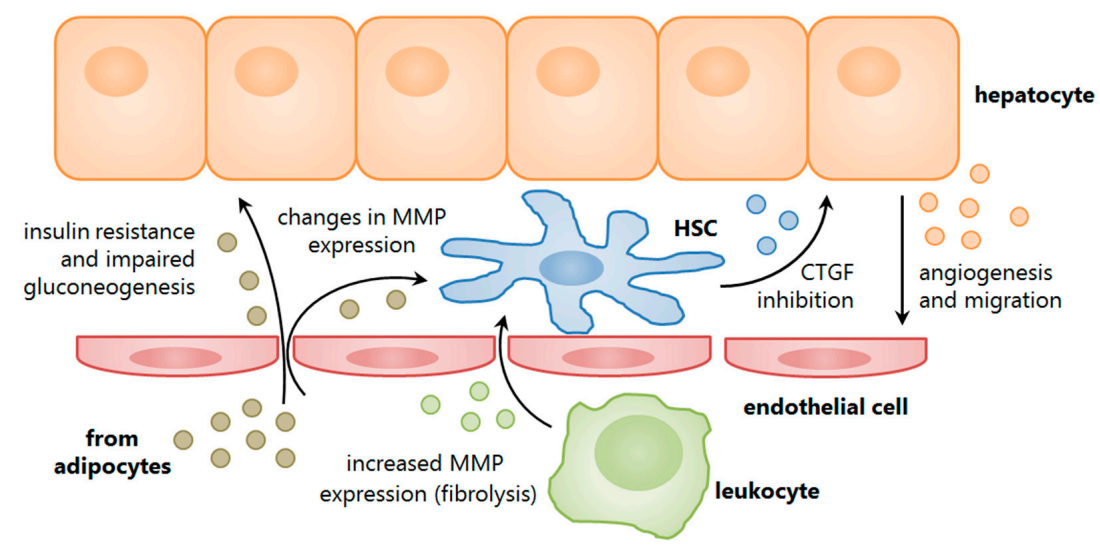

Figure 2. Extracellular vesicle roles in non-alcoholic fatty liver disease (NAFLD). EVs are involved in intercellular communication within the liver tissue, between hepatic cells as well as other tissues involved in mediating NAFLD pathogenesis, such as adipose and circulating (liver-homing) leukocytes. Collectively, these EVs are involved in a dynamic response that may exacerbate tissue injury, as well as promoting repair and matrix remodelling. Abbreviations: CTGF = connective tissue growth factor; $\mathrm{HSC}=$ hepatic stellate cell; MMP = matrix metalloproteinase.

\subsection{Animal Studies}

The fact that such issues remain to be addressed can be explained by the relative infancy of this field of research. To date, there are fewer than a dozen studies to have documented a role for EV signalling in a model of NAFLD, the earliest reported as late as 2009 in mice [79]. To better define a 
role for EVs in the development of hepatic steatosis, researchers have sought to replicate the clinical observations in rodent models of NAFLD, simulated by administering a choline-deficient diet (CDD) or high-fat diet (HFD) ad libitum for several weeks, the latter of which more accurately reflects the development of human metabolic syndrome. It should also be noted, that while CDD animals have comparable liver triglycerides to HFD animals, and a much more rapid progression to hepatic fibrosis, other typical changes such as increased body weight and fat depots, insulin resistance, and elevated fasting glucose and fatty acids are not observed [80]. This is due to the fact that, while HFD feeding increases lipid production, choline deficiency results in mitochondrial dysfunction and hence prevents the normal breakdown of lipids [81]. In saying that, contrary to what would be expected, EV studies in rodent models of NAFLD showed similar trends for both diets (see Table 2).

Table 2. Important findings for extracellular vesicles in the context of NAFLD.

\begin{tabular}{|c|c|c|c|c|c|}
\hline & Key Study Findings & Disease Model & Vesicle Source & Methods & Citation \\
\hline \multirow{5}{*}{ Rodent } & $\begin{array}{l}\text { NAFLD-inducing diet increases } \\
\text { circulating EV abundance }\end{array}$ & $\begin{array}{l}\text { HFD } \\
\text { CDD }\end{array}$ & plasma & FC & [74-76] \\
\hline & $\begin{array}{l}\text { Circulating EV abundance } \\
\text { correlates with NAFLD } \\
\text { progression }\end{array}$ & CDD & plasma & FC & {$[75,76]$} \\
\hline & $\begin{array}{l}\text { NAFLD-inducing diet increases } \\
\text { circulating liver-derived EVs }\end{array}$ & $\begin{array}{l}\text { HFD } \\
\text { CDD }\end{array}$ & $\begin{array}{l}\text { plasma } \\
\text { serum }\end{array}$ & RT-qPCR & [75-77] \\
\hline & $\begin{array}{l}\text { NAFLD-inducing diet changes } \\
\text { circulating EV contents }\end{array}$ & CDD & plasma & $\begin{array}{l}\text { LCMS } \\
\text { WB }\end{array}$ & {$[75,76]$} \\
\hline & $\begin{array}{c}\text { NAFLD-inducing diet changes } \\
\text { circulating EV interactions with } \\
\text { cells }\end{array}$ & HFD & plasma & FC & [79] \\
\hline \multirow{2}{*}{ Human } & $\begin{array}{c}\text { Circulating EV abundance } \\
\text { correlates with NAFLD } \\
\text { progression }\end{array}$ & NASH & plasma & FC & {$[72]$} \\
\hline & $\begin{array}{l}\text { Circulating EV contents can } \\
\text { distinguish NAFLD from other } \\
\text { liver diseases }\end{array}$ & $\mathrm{NASH}$ & $\begin{array}{l}\text { plasma } \\
\text { serum }\end{array}$ & $\begin{array}{l}\text { FC } \\
\text { microarray }\end{array}$ & {$[72,82]$} \\
\hline
\end{tabular}

Abbreviations: $\mathrm{CDD}=$ choline deficient diet, $\mathrm{EV}=$ extracellular vesicle, $\mathrm{FC}=$ flow cytometry, $\mathrm{HFD}=$ high-fat diet, LCMS = liquid chromatography with mass spectrometry, NAFLD = non-alcoholic fatty liver disease, $\mathrm{NASH}=$ non-alcoholic steatohepatitis, $\mathrm{RT}$-qPCR $=$ real-time quantitative polymerase chain reaction, $\mathrm{WB}=$ western blot.

In the original study, Deng and colleagues described a phenomenon in their chronic HFD model whereby circulating EVs that were adoptively transferred to healthy animals were engulfed by myeloid cells that subsequently accumulated in the liver [79]. This phenotype was not observed when EVs were transferred from animals on a normal chow diet, which may suggest a selective, EV-driven mechanism for hepatic inflammation as a concomitant to steatosis. While these findings are yet to be reproduced, other groups have instead begun to more comprehensively examine the profile of circulating EVs to better understand their temporal regulation, contents, and possible intervention strategies. Indeed it was shown that vesicles tend to increase on a background of NAFLD, and do so in a time-dependent manner, according to data obtained from flow cytometry experiments [74-76].

To evaluate how the liver contributes to this population, EVs were assessed for their expression of miRNA-122, a molecule that is enriched in mammalian livers and is shown to be involved in early NAFLD progression [83-85]. Consistent with previous findings, rodent studies confirmed an increase in circulating EV-associated miRNA-122 accompanied by a decrease in the liver expression of this molecule [75-77]. Furthermore, one study demonstrated that when miRNA-122 was trafficked in EVs, it was not associated with its protein binding partner Argonaute 2, a phenomenon that is 
otherwise typically observed in non-disease conditions [75]. While other miRNAs and proteins were not correlated against disease severity, Povero and colleagues had employed mass spectrometry to identify an EV-specific proteome in NAFLD that was distinct from healthy controls [75]. These findings complement a previous study done by the group, in which they confirm a role for EV-bound Vanin-1 in hepatocyte vesicle uptake by an endothelial cell line, with subsequent angiogenic behaviour that is only observed when EVs are derived from hepatocytes subjected to lipotoxic stress [76].

Taken together, these studies establish a solid foundation for understanding the role of EVs in NAFLD, however, some notable limitations exist. Firstly, changes in EV phenotype were not correlated against histological severity of liver disease, which would otherwise give some insight into their prognostic value. Furthermore, perhaps an emphasis on distinguishing NAFLD from other underlying liver pathologies would give EVs a stronger diagnostic utility, as had been addressed in the clinical studies below.

\subsection{Human Studies}

The pioneering study to involve human subjects was published three years later by Kornek and colleagues, who for the first time had suggested a correlation between the circulating abundance of leukocyte-derived EVs and disease severity, as determined by liver transaminase levels, biopsy grade, and NAFLD activity score (NAS) [72]. These findings still provide the most compelling evidence in clinical samples for the prognostic value of EVs in NASH development, and have been extensively cited. The authors have additionally noted a distinction between the circulating NAFLD EV profile and that seen in hepatitis $C$ patients. This is further supported by another study where transcriptomic analysis revealed that serum exosome-derived miRNAs are capable of differentiating multiple aetiologies of liver disease, as well as disease from normal liver controls [82]. Similar to the first study, it was shown that the expression level of some miRNAs was regulated either positively or negatively with histological features of disease, such as inflammation and fibrosis. However, these results were limited to the cohort with chronic hepatitis and no such data was available for NAFLD progression to NASH.

More recent studies have described the modulation of hepatocyte and stellate cell activity by EVs isolated from visceral (peritoneal) adipose tissue. While the subjects did not necessarily present with NAFLD, the ex vivo experimental designs instead aimed to establish a role for EVs in potentially mediating this disease. As such, Kranendonk and colleagues showed that adipocyte EVs from non-obese patients were capable of interfering with insulin signalling and gluconeogenesis when directly exposed to a hepatocyte cell line [78]. Furthermore, the concentration of EVs correlated positively with expression of liver transaminases, which supports the evidence for their role in hepatocyte dysfunction. In another study, albeit on a smaller scale, adipose tissue isolated from obese patients released EVs in culture that subsequently altered the gene expression of an MMP inhibitor, TIMP-1, in both hepatocytes and stellate cells [86]. Collectively, these findings suggest a novel mechanism of NAFLD pathogenesis by EVs through adipocyte-mediated hepatic cell stress and tissue remodelling.

\section{Understanding the Role of Secreted Vesicles}

With the urgency to develop a non-invasive biomarker for the diagnosis and staging of NAFLD, research into the biology of extracellular vesicles has provided an opportunity to explore a novel mechanism of disease pathogenesis that can also be harnessed as a clinical tool. However, there is still a long way to go before EV-related assays will have translational utility. Besides the obvious question of disease and tissue specificity, current techniques used in the isolation and characterisation of EVs remain laborious, and suffer from a lack of standardization, as well as high variability. It will undoubtedly take a few years before the processing of EVs from blood and other bodily fluids as "liquid biopsies" becomes economically viable, reproducible and validated. Until then we are unlikely to see their use in routine clinical practice. 
While much can be learned from the studies described in this review, the concept of analysing EVs in the context of NAFLD is still very much a small niche in the literature. One reason could be the limitations mentioned above, or a focus on more accessible biochemistries such as liver transaminases and soluble miRNA-122. But then why look at circulating EVs? Perhaps the answer lies in their active role in disease; they may not only confirm the presence of NAFLD, but also give an insight into which tissues are interacting and how this is driving pathogenesis. It has been shown that adipose tissue EVs taken from obese individuals are capable of signalling to hepatic cells to remodel their extracellular milieu, while these cells in turn may communicate via EVs with the sinusoid to promote angiogenesis $[76,86]$. Circulating vesicles have also been implicated in the innate immune response that accompanies steatosis, pointing to a role in the progression from early NAFLD to NASH [72,79]. From a physiological perspective, it makes sense to encapsulate certain molecules that are otherwise prone to enzymatic degradation, especially in a complex or unpredictable disease environment. However, if preservation of these molecules within EVs leads to a heightened stimulation of inflammatory cells, as previously suggested, this mechanism may in turn be responsible for the exacerbation of tissue injury.

Whether EVs can be considered as friend or foe in metabolic diseases is still a grey area, and likely depends on the tissue of origin. Their use as a biomarker is further complicated by the possibility of temporal fluctuation or waning, as is seen with liver enzymes in models of NAFLD [87,88], which limits their predictive value. Furthermore, high-powered micrographs of liver sections have shown that hepatic EVs are predominantly located in the perisinusoidal region $[75,76]$, which may indicate their entrapment in the liver, contrary to previous findings described in this review and also within the same studies. This idea is supported by the fact that the sinusoidal endothelium undergoes defenestration with progressive fibrosis, as well as aging [89], which may restrict the normal flux of vesicles and macromolecules within the liver. Alternatively, the accumulation of fibrous tissue in the perisinusoid may also limit the passage of EVs, or provide selective permeability to smaller vesicles. However, whether this is a protective mechanism or passive consequence of disease is yet to be elucidated.

\section{What Does the Future Hold?}

The multifaceted nature of EVs suggests that these structures may have potential value beyond their use as circulating biomarkers in NAFLD. For instance, cancer studies have explored the transfer of oncogenes and an oncogenic phenotype through EV uptake in cell culture models [41,90,91], which may provide a target for therapeutic intervention. Indeed, it was shown that incubating hepatoma cells with various anti-cancer drugs promoted the secretion of immunogenic EVs that were capable of enhancing natural killer (NK) cell responses [55,56]. Conversely, exposing macrophages to such drugs may induce the release of EV-derived miRNAs, which suppress cancer growth by epigenetic regulation [57]. This concept has been extended to NAFLD models, where it was found that administering cholesterol-lowering drugs to high-fat fed rodents can attenuate the release of EVs, however the exact implication of this was not discussed, except for a potential reduction in liver cell death $[73,74]$.

Another approach is to use the vesicles themselves as a mode or target of therapy, not simply a marker of injury. This idea has been investigated since the late 1980s, whereby synthetic EVs were used as a vehicle for drug delivery in both in vitro and in vivo models of liver injury [92,93]. It is also possible that in the future, endogenous EVs may be harvested for similar purposes, providing an efficient technique for tissue-specific delivery of molecules. The advantage of this autologous transfer system is that the vesicles are less likely to be rejected by the patient, however still sufficiently immunogenic to elicit a response [79].

\section{Conclusions}

With the rapid advancement of technology, it can be expected that once EVs become a routine parameter for assessment of disease status - of especial value in conditions that are difficult to diagnose, 
such as NAFLD - their utility may be further projected to the treatment of disease in its early stages, and potentially the reversal of chronic disorders like NASH. While there is still a long way to go, for the time being it is important to focus on controlling the underlying metabolic disorders through traditional intervention methods and lifestyle changes, which would also slow the progression of its comorbidities. However, detection of NAFLD and its staging continues to be a problem with invasive techniques such as biopsy being the gold standard. For this reason, EV analysis has promise as a non-invasive diagnostic tool.

Acknowledgments: Linda A. Ban is supported by a grant from the Greg Brown Diabetes and Endocrine Trust Fund.

Author Contributions: Linda A. Ban and Susan V. McLennan conceived the study; Linda A. Ban and Nicholas A. Shackel designed the figures; Susan V. McLennan and Nicholas A. Shackel reviewed/edited the manuscript; Linda A. Ban researched the data and wrote the manuscript.

Conflicts of Interest: The authors declare no conflict of interest.

\section{Abbreviations}

The following abbreviations are used in this manuscript:

$\begin{array}{ll}\text { ALT } & \text { alanine transaminase } \\ \text { ASGPR1 } & \text { asialoglycoprotein receptor } 1 \\ \text { CDD } & \text { choline-deficient diet } \\ \text { CES1 } & \text { carboxylesterase 1 } \\ \text { CTGF } & \text { connective tissue growth factor } \\ \text { ESCRT } & \text { endosomal sorting complex required for transport } \\ \text { EV } & \text { extracellular vesicle } \\ \text { FC } & \text { flow cytometry } \\ \text { HFD } & \text { high-fat diet } \\ \text { HSC } & \text { hepatic stellate cell } \\ \text { IL-6 } & \text { interleukin } 6 \\ \text { iNKT } & \text { invariant natural killer T cell } \\ \text { LCHS } / \text { MS } & \text { liquid chromatography with tandem mass spectrometry } \\ \text { MCP-1 } & \text { monocyte chemotactic protein 1 } \\ \text { MIF } & \text { [macrophage] migration inhibitory factor } \\ \text { miRNA } & \text { microRNA } \\ \text { MMP } & \text { matrix metalloproteinase } \\ \text { MV } & \text { microvesicle } \\ \text { MVB } & \text { multivesicular body } \\ \text { NAFLD } & \text { non-alcoholic fatty liver disease } \\ \text { NAS } & \text { NAFLD activity score } \\ \text { NASH } & \text { non-alcoholic steatohepatitis } \\ \text { NK } & \text { natural killer cell } \\ \text { ed1 } & \text { phosphatidylserine } \\ \text { RT-qPCR } & \text { real-time quantitative polymerase chain reaction } \\ \text { TEM } & \text { transmission electron microscopy } \\ \text { TIMP-1 } & \text { tissue inhibitor of metalloproteinase 1 } \\ \text { WB } & \text { western blot } \\ \text { WGO } & \text { World Gastroenterology Organisation } \\ & \end{array}$

\section{References}

1. Hui, E.; Xu, A.; Bo Yang, H.; Lam, K.S. Obesity as the common soil of non-alcoholic fatty liver disease and diabetes: Role of adipokines. J. Diabetes Investig. 2013, 4, 413-425. [CrossRef] [PubMed] 
2. Bugianesi, E.; Vanni, E.; Marchesini, G. NASH and the risk of cirrhosis and hepatocellular carcinoma in type 2 diabetes. Curr. Diabetes Rep. 2007, 7, 175-180. [CrossRef]

3. Williams, K.H.; Shackel, N.A.; Gorrell, M.D.; McLennan, S.V.; Twigg, S.M. Diabetes and nonalcoholic fatty liver disease: A pathogenic duo. Endocr. Rev. 2013, 34, 84-129. [CrossRef] [PubMed]

4. Adams, L.A.; Harmsen, S.; St Sauver, J.L.; Charatcharoenwitthaya, P.; Enders, F.B.; Therneau, T.; Angulo, P. Nonalcoholic fatty liver disease increases risk of death among patients with diabetes: A community-based cohort study. Am. J. Gastroenterol. 2010, 105, 1567-1573. [CrossRef] [PubMed]

5. Feng, R.N.; Du, S.S.; Wang, C.; Li, Y.C.; Liu, L.Y.; Guo, F.C.; Sun, C.H. Lean-non-alcoholic fatty liver disease increases risk for metabolic disorders in a normal weight chinese population. World J. Gastroenterol. 2014, 20, 17932-17940. [PubMed]

6. Kumar, R.; Rastogi, A.; Sharma, M.K.; Bhatia, V.; Garg, H.; Bihari, C.; Sarin, S.K. Clinicopathological characteristics and metabolic profiles of non-alcoholic fatty liver disease in indian patients with normal body mass index: Do they differ from obese or overweight non-alcoholic fatty liver disease? Indian J. Endocrinol. Metab. 2013, 17, 665-671. [CrossRef] [PubMed]

7. Younossi, Z.M.; Stepanova, M.; Negro, F.; Hallaji, S.; Younossi, Y.; Lam, B.; Srishord, M. Nonalcoholic fatty liver disease in lean individuals in the united states. Medicine 2012, 91, 319-327. [CrossRef] [PubMed]

8. LaBrecque, D.R.; Abbas, Z.; Anania, F.; Ferenci, P.; Khan, A.G.; Goh, K.L.; Hamid, S.S.; Isakov, V.; Lizarzabal, M.; Penaranda, M.M.; et al. World gastroenterology organisation global guidelines: Nonalcoholic fatty liver disease and nonalcoholic steatohepatitis. J. Clin. Gastroenterol. 2014, 48, 467-473. [CrossRef] [PubMed]

9. Deffieux, T.; Gennisson, J.L.; Bousquet, L.; Corouge, M.; Cosconea, S.; Amroun, D.; Tripon, S.; Terris, B.; Mallet, V.; Sogni, P.; et al. Investigating liver stiffness and viscosity for fibrosis, steatosis and activity staging using shear wave elastography. J. Hepatol. 2015, 62, 317-324. [CrossRef] [PubMed]

10. Khov, N.; Sharma, A.; Riley, T.R. Bedside ultrasound in the diagnosis of nonalcoholic fatty liver disease. World J. Gastroenterol. 2014, 20, 6821-6825. [CrossRef] [PubMed]

11. Myers, R.P.; Pomier-Layrargues, G.; Kirsch, R.; Pollett, A.; Beaton, M.; Levstik, M.; Duarte-Rojo, A.; Wong, D.; Crotty, P.; Elkashab, M. Discordance in fibrosis staging between liver biopsy and transient elastography using the FibroScan XL probe. J. Hepatol. 2012, 56, 564-570. [CrossRef] [PubMed]

12. Myers, R.P.; Pomier-Layrargues, G.; Kirsch, R.; Pollett, A.; Duarte-Rojo, A.; Wong, D.; Beaton, M.; Levstik, M.; Crotty, P.; Elkashab, M. Feasibility and diagnostic performance of the FibroScan XL probe for liver stiffness measurement in overweight and obese patients. Hepatology 2012, 55, 199-208. [CrossRef] [PubMed]

13. Pais, R.; Charlotte, F.; Fedchuk, L.; Bedossa, P.; Lebray, P.; Poynard, T.; Ratziu, V.; Group, L.S. A systematic review of follow-up biopsies reveals disease progression in patients with non-alcoholic fatty liver. J. Hepatol. 2013, 59, 550-556. [CrossRef] [PubMed]

14. Zelber-Sagi, S.; Yeshua, H.; Shlomai, A.; Blendis, L.; Leshno, M.; Levit, S.; Halpern, Z.; Oren, R. Sampling variability of transient elastography according to probe location. Eur. J. Gastroenterol. Hepatol. 2011, 23, 507-514. [CrossRef] [PubMed]

15. Athyros, V.G.; Katsiki, N.; Karagiannis, A.; Mikhailidis, D.P. Statins and nonalcoholic fatty liver disease: A bright future? Expert Opin. Investig. Drugs 2013, 22, 1089-1093. [CrossRef] [PubMed]

16. Angulo, P. Long-term mortality in nonalcoholic fatty liver disease: Is liver histology of any prognostic significance? Hepatology 2010, 51, 373-375. [CrossRef] [PubMed]

17. Arun, J.; Jhala, N.; Lazenby, A.J.; Clements, R.; Abrams, G.A. Influence of liver biopsy heterogeneity and diagnosis of nonalcoholic steatohepatitis in subjects undergoing gastric bypass. Obes. Surg. 2007, 17, 155-161. [CrossRef] [PubMed]

18. Wolf, P. The nature and significance of platelet products in human plasma. Br. J. Haematol. 1967, 13, 269-288. [CrossRef] [PubMed]

19. Dalton, A.J. Microvesicles and vesicles of multivesicular bodies versus "virus-like" particles. J. Natl. Cancer Inst. 1975, 54, 1137-1148.

20. Bala, S.; Petrasek, J.; Mundkur, S.; Catalano, D.; Levin, I.; Ward, J.; Alao, H.; Kodys, K.; Szabo, G. Circulating microRNAs in exosomes indicate hepatocyte injury and inflammation in alcoholic, drug-induced, and inflammatory liver diseases. Hepatology 2012, 56, 1946-1957. [CrossRef] [PubMed]

21. Kornek, M.; Schuppan, D. Microparticles: Modulators and biomarkers of liver disease. J. Hepatol. 2012, 57, 1144-1146. [CrossRef] [PubMed] 
22. Lemoinne, S.; Thabut, D.; Housset, C.; Moreau, R.; Valla, D.; Boulanger, C.M.; Rautou, P.E. The emerging roles of microvesicles in liver diseases. Nat. Rev. Gastroenterol. Hepatol. 2014, 11, 350-361. [CrossRef] [PubMed]

23. Royo, F.; Falcon-Perez, J.M. Liver extracellular vesicles in health and disease. J. Extracell. Vesicles $2012,1$. [CrossRef] [PubMed]

24. Ferrante, S.C.; Nadler, E.P.; Pillai, D.K.; Hubal, M.J.; Wang, Z.; Wang, J.M.; Gordish-Dressman, H.; Koeck, E.; Sevilla, S.; Wiles, A.A.; et al. Adipocyte-derived exosomal miRNAs: A novel mechanism for obesity-related disease. Pediatr. Res. 2015, 77, 447-454. [CrossRef] [PubMed]

25. Goichot, B.; Grunebaum, L.; Desprez, D.; Vinzio, S.; Meyer, L.; Schlienger, J.L.; Lessard, M.; Simon, C. Circulating procoagulant microparticles in obesity. Diabetes Metab. 2006, 32, 82-85. [CrossRef]

26. Nomura, S.; Inami, N.; Shouzu, A.; Urase, F.; Maeda, Y. Correlation and association between plasma platelet-, monocyte- and endothelial cell-derived microparticles in hypertensive patients with type 2 diabetes mellitus. Platelets 2009, 20, 406-414. [CrossRef] [PubMed]

27. Wang, Y.; Chen, L.M.; Liu, M.L. Microvesicles and diabetic complications-Novel mediators, potential biomarkers and therapeutic targets. Acta Pharmacol. Sin. 2014, 35, 433-443. [CrossRef] [PubMed]

28. Akers, J.C.; Gonda, D.; Kim, R.; Carter, B.S.; Chen, C.C. Biogenesis of extracellular vesicles (EV): Exosomes, microvesicles, retrovirus-like vesicles, and apoptotic bodies. J. Neuro-Oncol. 2013, 113, 1-11. [CrossRef] [PubMed]

29. Cocucci, E.; Meldolesi, J. Ectosomes and exosomes: Shedding the confusion between extracellular vesicles. Trends Cell Biol. 2015, 25, 364-372. [CrossRef] [PubMed]

30. Kreimer, S.; Belov, A.M.; Ghiran, I.; Murthy, S.K.; Frank, D.A.; Ivanov, A.R. Mass-spectrometry-based molecular characterization of extracellular vesicles: Lipidomics and proteomics. J. Proteome Res. 2015, 14, 2367-2384. [CrossRef] [PubMed]

31. Hurley, J.H.; Odorizzi, G. Get on the exosome bus with ALIX. Nat. Cell Biol. 2012, 14, 654-655. [CrossRef] [PubMed]

32. Pols, M.S.; Klumperman, J. Trafficking and function of the tetraspanin CD63. Exp. Cell Res. 2009, 315, 1584-1592. [CrossRef] [PubMed]

33. Schutters, K.; Reutelingsperger, C. Phosphatidylserine targeting for diagnosis and treatment of human diseases. Apoptosis Int. J. Program. Cell Death 2010, 15, 1072-1082. [CrossRef] [PubMed]

34. Spronk, H.M.; ten Cate, H.; van der Meijden, P.E. Differential roles of tissue factor and phosphatidylserine in activation of coagulation. Thromb. Res. 2014, 133, S54-S56. [CrossRef] [PubMed]

35. Albanyan, A.M.; Murphy, M.F.; Rasmussen, J.T.; Heegaard, C.W.; Harrison, P. Measurement of phosphatidylserine exposure during storage of platelet concentrates using the novel probe lactadherin: A comparison study with annexin V. Transfusion 2009, 49, 99-107. [CrossRef] [PubMed]

36. Connor, D.E.; Exner, T.; Ma, D.D.; Joseph, J.E. The majority of circulating platelet-derived microparticles fail to bind annexin $\mathrm{V}$, lack phospholipid-dependent procoagulant activity and demonstrate greater expression of glycoprotein Ib. Thromb. Haemost. 2010, 103, 1044-1052. [CrossRef] [PubMed]

37. Dasgupta, S.K.; Guchhait, P.; Thiagarajan, P. Lactadherin binding and phosphatidylserine expression on cell surface-comparison with annexin A5. Transl. Res. J. Lab. Clin. Med. 2006, 148, 19-25. [CrossRef] [PubMed]

38. Quesenberry, P.J.; Goldberg, L.R.; Aliotta, J.M.; Dooner, M.S.; Pereira, M.G.; Wen, S.; Camussi, G. Cellular phenotype and extracellular vesicles: Basic and clinical considerations. Stem Cells Dev. 2014, 23, 1429-1436. [CrossRef] [PubMed]

39. Xiong, W.; Sun, L.P.; Chen, X.M.; Li, H.Y.; Huang, S.A.; Jie, S.H. Comparison of microRNA expression profiles in HCC-derived microvesicles and the parental cells and evaluation of their roles in HCC. J. Huazhong Univ. Sci. Technol. Med. Sci. 2013, 33, 346-352. [CrossRef] [PubMed]

40. Witwer, K.W.; Buzas, E.I.; Bemis, L.T.; Bora, A.; Lasser, C.; Lotvall, J.; Nolte-'t Hoen, E.N.; Piper, M.G.; Sivaraman, S.; Skog, J.; et al. Standardization of sample collection, isolation and analysis methods in extracellular vesicle research. J. Extracell. Vesicles 2013, 2. [CrossRef] [PubMed]

41. Bergsmedh, A.; Szeles, A.; Henriksson, M.; Bratt, A.; Folkman, M.J.; Spetz, A.L.; Holmgren, L. Horizontal transfer of oncogenes by uptake of apoptotic bodies. Proc. Natl. Acad. Sci. USA 2001, 98, 6407-6411. [CrossRef] [PubMed]

42. Elmore, S. Apoptosis: A review of programmed cell death. Toxicol. Pathol. 2007, 35, 495-516. [CrossRef] [PubMed] 
43. Lynch, S.F.; Ludlam, C.A. Plasma microparticles and vascular disorders. Br. J. Haematol. 2007, 137, $36-48$. [CrossRef] [PubMed]

44. Ogasawara, F.; Fusegawa, H.; Haruki, Y.; Shiraishi, K.; Watanabe, N.; Matsuzaki, S. Platelet activation in patients with alcoholic liver disease. Tokai J. Exp. Clin. Med. 2005, 30, 41-48. [PubMed]

45. Stravitz, R.T.; Bowling, R.; Bradford, R.L.; Key, N.S.; Glover, S.; Thacker, L.R.; Gabriel, D.A. Role of procoagulant microparticles in mediating complications and outcome of acute liver injury/acute liver failure. Hepatology 2013, 58, 304-313. [CrossRef] [PubMed]

46. Bernimoulin, M.; Waters, E.K.; Foy, M.; Steele, B.M.; Sullivan, M.; Falet, H.; Walsh, M.T.; Barteneva, N.; Geng, J.G.; Hartwig, J.H.; et al. Differential stimulation of monocytic cells results in distinct populations of microparticles. J. Thromb. Haemost. 2009, 7, 1019-1028. [CrossRef] [PubMed]

47. Charrier, A.; Chen, R.; Chen, L.; Kemper, S.; Hattori, T.; Takigawa, M.; Brigstock, D.R. Exosomes mediate intercellular transfer of pro-fibrogenic connective tissue growth factor (CCN2) between hepatic stellate cells, the principal fibrotic cells in the liver. Surgery 2014, 156, 548-555. [CrossRef] [PubMed]

48. Chen, L.; Charrier, A.; Zhou, Y.; Chen, R.; Yu, B.; Agarwal, K.; Tsukamoto, H.; Lee, L.J.; Paulaitis, M.E.; Brigstock, D.R. Epigenetic regulation of connective tissue growth factor by microRNA-214 delivery in exosomes from mouse or human hepatic stellate cells. Hepatology 2014, 59, 1118-1129. [CrossRef] [PubMed]

49. Kornek, M.; Popov, Y.; Libermann, T.A.; Afdhal, N.H.; Schuppan, D. Human t cell microparticles circulate in blood of hepatitis patients and induce fibrolytic activation of hepatic stellate cells. Hepatology 2011, 53, 230-242. [CrossRef] [PubMed]

50. Kogure, T.; Lin, W.L.; Yan, I.K.; Braconi, C.; Patel, T. Intercellular nanovesicle-mediated microRNA transfer: A mechanism of environmental modulation of hepatocellular cancer cell growth. Hepatology 2011, 54, 1237-1248. [CrossRef] [PubMed]

51. Kogure, T.; Yan, I.K.; Lin, W.L.; Patel, T. Extracellular vesicle-mediated transfer of a novel long noncoding RNA TUC339: A mechanism of intercellular signaling in human hepatocellular cancer. Genes Cancer 2013, 4, 261-272. [CrossRef] [PubMed]

52. Fonsato, V.; Collino, F.; Herrera, M.B.; Cavallari, C.; Deregibus, M.C.; Cisterna, B.; Bruno, S.; Romagnoli, R.; Salizzoni, M.; Tetta, C.; et al. Human liver stem cell-derived microvesicles inhibit hepatoma growth in scid mice by delivering antitumor microRNAs. Stem Cells 2012, 30, 1985-1998. [CrossRef] [PubMed]

53. Momen-Heravi, F.; Bala, S.; Kodys, K.; Szabo, G. Exosomes derived from alcohol-treated hepatocytes horizontally transfer liver specific miRNA-122 and sensitize monocytes to LPS. Sci. Rep. 2015, 5, 9991. [CrossRef] [PubMed]

54. Takahashi, K.; Yan, I.K.; Kogure, T.; Haga, H.; Patel, T. Extracellular vesicle-mediated transfer of long non-coding RNA ror modulates chemosensitivity in human hepatocellular cancer. FEBS Open Bio 2014, 4, 458-467. [CrossRef] [PubMed]

55. Lv, L.H.; Wan, Y.L.; Lin, Y.; Zhang, W.; Yang, M.; Li, G.L.; Lin, H.M.; Shang, C.Z.; Chen, Y.J.; Min, J. Anticancer drugs cause release of exosomes with heat shock proteins from human hepatocellular carcinoma cells that elicit effective natural killer cell antitumor responses in vitro. J. Biol. Chem. 2012, 287, 15874-15885. [CrossRef] [PubMed]

56. Xiao, W.; Dong, W.; Zhang, C.; Saren, G.; Geng, P.; Zhao, H.; Li, Q.; Zhu, J.; Li, G.; Zhang, S.; et al. Effects of the epigenetic drug MS-275 on the release and function of exosome-related immune molecules in hepatocellular carcinoma cells. Eur. J. Med. Res. 2013, 18, 61. [CrossRef] [PubMed]

57. Zhang, J.; Shan, W.F.; Jin, T.T.; Wu, G.Q.; Xiong, X.X.; Jin, H.Y.; Zhu, S.M. Propofol exerts anti-hepatocellular carcinoma by microvesicle-mediated transfer of miR-142-3p from macrophage to cancer cells. J. Transl. Med. 2014, 12, 279. [CrossRef] [PubMed]

58. Li, Y.; Zhang, L.; Liu, F.; Xiang, G.; Jiang, D.; Pu, X. Identification of endogenous controls for analyzing serum exosomal miRNA in patients with hepatitis B or hepatocellular carcinoma. Dis. Markers 2015, 2015, 893594. [CrossRef] [PubMed]

59. Sugimachi, K.; Matsumura, T.; Hirata, H.; Uchi, R.; Ueda, M.; Ueo, H.; Shinden, Y.; Iguchi, T.; Eguchi, H.; Shirabe, K.; et al. Identification of a bona fide microRNA biomarker in serum exosomes that predicts hepatocellular carcinoma recurrence after liver transplantation. Br. J. Cancer 2015, 112, 532-538. [CrossRef] [PubMed]

60. Sun, L.; Hu, J.; Xiong, W.; Chen, X.; Li, H.; Jie, S. MicroRNA expression profiles of circulating microvesicles in hepatocellular carcinoma. Acta Gastro-Enterol. Belg. 2013, 76, 386-392. 
61. Wang, H.; Hou, L.; Li, A.; Duan, Y.; Gao, H.; Song, X. Expression of serum exosomal microRNA-21 in human hepatocellular carcinoma. BioMed Res. Int. 2014, 2014, 864894. [CrossRef] [PubMed]

62. Brodsky, S.V.; Facciuto, M.E.; Heydt, D.; Chen, J.; Islam, H.K.; Kajstura, M.; Ramaswamy, G.; Aguero-Rosenfeld, M. Dynamics of circulating microparticles in liver transplant patients. J. Gastrointest. Liver Dis. 2008, 17, 261-268.

63. Freeman, C.M.; Quillin, R.C., 3rd; Wilson, G.C.; Nojima, H.; Johnson, B.L., 3rd; Sutton, J.M.; Schuster, R.M.; Blanchard, J.; Edwards, M.J.; Caldwell, C.C.; et al. Characterization of microparticles after hepatic ischemia-reperfusion injury. PLoS ONE 2014, 9, e97945. [CrossRef] [PubMed]

64. Costa-Silva, B.; Aiello, N.M.; Ocean, A.J.; Singh, S.; Zhang, H.; Thakur, B.K.; Becker, A.; Hoshino, A.; Mark, M.T.; Molina, H.; et al. Pancreatic cancer exosomes initiate pre-metastatic niche formation in the liver. Nat. Cell Biol. 2015, 17, 816-826. [CrossRef] [PubMed]

65. Eldh, M.; Olofsson Bagge, R.; Lasser, C.; Svanvik, J.; Sjostrand, M.; Mattsson, J.; Lindner, P.; Choi, D.S.; Gho, Y.S.; Lotvall, J. MicroRNA in exosomes isolated directly from the liver circulation in patients with metastatic uveal melanoma. BMC Cancer 2014, 14, 962. [CrossRef] [PubMed]

66. Wang, X.; Ding, X.; Nan, L.; Wang, Y.; Wang, J.; Yan, Z.; Zhang, W.; Sun, J.; Zhu, W.; Ni, B.; et al. Investigation of the roles of exosomes in colorectal cancer liver metastasis. Oncol. Rep. 2015, 33, 2445-2453. [CrossRef] [PubMed]

67. Calabro, S.R.; Maczurek, A.E.; Morgan, A.J.; Tu, T.; Wen, V.W.; Yee, C.; Mridha, A.; Lee, M.; d'Avigdor, W.; Locarnini, S.A.; et al. Hepatocyte produced matrix metalloproteinases are regulated by CD147 in liver fibrogenesis. PLoS ONE 2014, 9, e90571. [CrossRef] [PubMed]

68. Lee, A.; Rode, A.; Nicoll, A.; Maczurek, A.E.; Lim, L.; Lim, S.; Angus, P.; Kronborg, I.; Arachchi, N.; Gorelik, A.; et al. Circulating CD147 predicts mortality in advanced hepatocellular carcinoma. J. Gastroenterol. Hepatol. 2016, 31, 459-466. [CrossRef] [PubMed]

69. Sidhu, S.S.; Mengistab, A.T.; Tauscher, A.N.; LaVail, J.; Basbaum, C. The microvesicle as a vehicle for emmprin in tumor-stromal interactions. Oncogene 2004, 23, 956-963. [CrossRef] [PubMed]

70. Millimaggi, D.; Mari, M.; D’Ascenzo, S.; Carosa, E.; Jannini, E.A.; Zucker, S.; Carta, G.; Pavan, A.; Dolo, V. Tumor vesicle-associated CD147 modulates the angiogenic capability of endothelial cells. Neoplasia 2007, 9 , 349-357. [CrossRef] [PubMed]

71. Zhang, W.; Zhao, P.; Xu, X.L.; Cai, L.; Song, Z.S.; Cao, D.Y.; Tao, K.S.; Zhou, W.P.; Chen, Z.N.; Dou, K.F. Annexin A2 promotes the migration and invasion of human hepatocellular carcinoma cells in vitro by regulating the shedding of CD147-harboring microvesicles from tumor cells. PLoS ONE 2013, 8, e67268. [CrossRef] [PubMed]

72. Kornek, M.; Lynch, M.; Mehta, S.H.; Lai, M.; Exley, M.; Afdhal, N.H.; Schuppan, D. Circulating microparticles as disease-specific biomarkers of severity of inflammation in patients with hepatitis c or nonalcoholic steatohepatitis. Gastroenterology 2012, 143, 448-458. [CrossRef] [PubMed]

73. Baron, M.; Leroyer, A.S.; Majd, Z.; Lalloyer, F.; Vallez, E.; Bantubungi, K.; Chinetti-Gbaguidi, G.; Delerive, P.; Boulanger, C.M.; Staels, B.; et al. PPAR $\alpha$ activation differently affects microparticle content in atherosclerotic lesions and liver of a mouse model of atherosclerosis and NASH. Atherosclerosis 2011, 218, 69-76. [CrossRef] [PubMed]

74. Ajamieh, H.; Farrell, G.C.; McCuskey, R.S.; Yu, J.; Chu, E.; Wong, H.J.; Lam, W.; Teoh, N.C. Acute atorvastatin is hepatoprotective against ischaemia-reperfusion injury in mice by modulating enos and microparticle formation. Liver Int. 2015, 35, 2174-2186. [CrossRef] [PubMed]

75. Povero, D.; Eguchi, A.; Li, H.; Johnson, C.D.; Papouchado, B.G.; Wree, A.; Messer, K.; Feldstein, A.E. Circulating extracellular vesicles with specific proteome and liver microRNAs are potential biomarkers for liver injury in experimental fatty liver disease. PLoS ONE 2014, 9, e113651. [CrossRef] [PubMed]

76. Povero, D.; Eguchi, A.; Niesman, I.R.; Andronikou, N.; de Mollerat du Jeu, X.; Mulya, A.; Berk, M.; Lazic, M.; Thapaliya, S.; Parola, M.; et al. Lipid-induced toxicity stimulates hepatocytes to release angiogenic microparticles that require vanin-1 for uptake by endothelial cells. Sci. Signal. 2013, 6, ra88. [CrossRef] [PubMed]

77. Csak, T.; Bala, S.; Lippai, D.; Satishchandran, A.; Catalano, D.; Kodys, K.; Szabo, G. MicroRNA-122 regulates hypoxia-inducible factor- 1 and vimentin in hepatocytes and correlates with fibrosis in diet-induced steatohepatitis. Liver Int. 2015, 35, 532-541. [CrossRef] [PubMed] 
78. Kranendonk, M.E.; Visseren, F.L.; van Herwaarden, J.A.; Nolte-'t Hoen, E.N.; de Jager, W.; Wauben, M.H.; Kalkhoven, E. Effect of extracellular vesicles of human adipose tissue on insulin signaling in liver and muscle cells. Obesity 2014, 22, 2216-2223. [CrossRef] [PubMed]

79. Deng, Z.B.; Liu, Y.; Liu, C.; Xiang, X.; Wang, J.; Cheng, Z.; Shah, S.V.; Zhang, S.; Zhang, L.; Zhuang, X.; et al . Immature myeloid cells induced by a high-fat diet contribute to liver inflammation. Hepatology 2009, 50, 1412-1420. [CrossRef] [PubMed]

80. Raubenheimer, P.J.; Nyirenda, M.J.; Walker, B.R. A choline-deficient diet exacerbates fatty liver but attenuates insulin resistance and glucose intolerance in mice fed a high-fat diet. Diabetes 2006, 55, 2015-2020. [CrossRef] [PubMed]

81. Anstee, Q.M.; Goldin, R.D. Mouse models in non-alcoholic fatty liver disease and steatohepatitis research. Int. J. Exp. Pathol. 2006, 87, 1-16. [CrossRef] [PubMed]

82. Murakami, Y.; Toyoda, H.; Tanahashi, T.; Tanaka, J.; Kumada, T.; Yoshioka, Y.; Kosaka, N.; Ochiya, T.; Taguchi, Y.H. Comprehensive miRNA expression analysis in peripheral blood can diagnose liver disease. PLOS ONE 2012, 7, e48366.

83. Lagos-Quintana, M.; Rauhut, R.; Yalcin, A.; Meyer, J.; Lendeckel, W.; Tuschl, T. Identification of tissue-specific microRNAs from mouse. Curr. Biol. CB 2002, 12, 735-739. [PubMed]

84. Barad, O.; Meiri, E.; Avniel, A.; Aharonov, R.; Barzilai, A.; Bentwich, I.; Einav, U.; Gilad, S.; Hurban, P.; Karov, Y.; et al. MicroRNA expression detected by oligonucleotide microarrays: System establishment and expression profiling in human tissues. Gen. Res. 2004, 14, 2486-2494. [CrossRef] [PubMed]

85. Yamada, H.; Ohashi, K.; Suzuki, K.; Munetsuna, E.; Ando, Y.; Yamazaki, M.; Ishikawa, H.; Ichino, N.; Teradaira, R.; Hashimoto, S. Longitudinal study of circulating miR-122 in a rat model of non-alcoholic fatty liver disease. Clin. Chim. Acta Int. J. Clin. Chem. 2015, 446, 267-271. [CrossRef] [PubMed]

86. Koeck, E.S.; Iordanskaia, T.; Sevilla, S.; Ferrante, S.C.; Hubal, M.J.; Freishtat, R.J.; Nadler, E.P. Adipocyte exosomes induce transforming growth factor $\beta$ pathway dysregulation in hepatocytes: A novel paradigm for obesity-related liver disease. J. Surg. Res. 2014, 192, 268-275. [CrossRef] [PubMed]

87. Itagaki, H.; Shimizu, K.; Morikawa, S.; Ogawa, K.; Ezaki, T. Morphological and functional characterization of non-alcoholic fatty liver disease induced by a methionine-choline-deficient diet in c57bl/6 mice. Int. J. Clin. Exp. Pathol. 2013, 6, 2683-2696. [PubMed]

88. Verma, S.; Jensen, D.; Hart, J.; Mohanty, S.R. Predictive value of alt levels for non-alcoholic steatohepatitis (NASH) and advanced fibrosis in non-alcoholic fatty liver disease (NAFLD). Liver Int. 2013, 33, 1398-1405. [CrossRef] [PubMed]

89. Fraser, R.; Cogger, V.C.; Dobbs, B.; Jamieson, H.; Warren, A.; Hilmer, S.N.; le Couteur, D.G. The liver sieve and atherosclerosis. Pathology 2012, 44, 181-186. [CrossRef] [PubMed]

90. Redzic, J.S.; Kendrick, A.A.; Bahmed, K.; Dahl, K.D.; Pearson, C.G.; Robinson, W.A.; Robinson, S.E.; Graner, M.W.; Eisenmesser, E.Z. Extracellular vesicles secreted from cancer cell lines stimulate secretion of MMP-9, IL-6, TGF- $\beta 1$ and emmprin. PLoS ONE 2013, 8, e71225. [CrossRef] [PubMed]

91. He, M.; Qin, H.; Poon, T.C.; Sze, S.C.; Ding, X.; Co, N.N.; Ngai, S.M.; Chan, T.F.; Wong, N. Hepatocellular carcinoma-derived exosomes promote motility of immortalized hepatocyte through transfer of oncogenic proteins and RNAs. Carcinogenesis 2015, 36, 1008-1018. [CrossRef] [PubMed]

92. Farazuddin, M.; Dua, B.; Zia, Q.; Khan, A.A.; Joshi, B.; Owais, M. Chemotherapeutic potential of curcumin-bearing microcells against hepatocellular carcinoma in model animals. Int. J. Nanomed. 2014, 9, 1139-1152.

93. Laakso, T.; Edman, P.; Brunk, U. Biodegradable microspheres VII: Alterations in mouse liver morphology after intravenous administration of polyacryl starch microparticles with different biodegradability. J. Pharm. Sci. 1988, 77, 138-144. [CrossRef] [PubMed]

(C) 2016 by the authors; licensee MDPI, Basel, Switzerland. This article is an open access article distributed under the terms and conditions of the Creative Commons by Attribution (CC-BY) license (http://creativecommons.org/licenses/by/4.0/). 